Article

\title{
Towards Contextualized Islamic Leadership: Paraguiding and the Universities and Muslim Seminaries Project (UMSEP)
}

\author{
Alison Scott-Baumann ${ }^{1, *(\mathbb{D}}$, Alyaa Ebbiary ${ }^{1}$, Shams Ad Duha Mohammad ${ }^{2}{ }^{\oplus}$, Safiyya Dhorat ${ }^{2}$, \\ Shahanaz Begum ${ }^{2}$, Hasan Pandor ${ }^{1}$ and Julia Stolyar ${ }^{1}$ \\ 1 School of Oriental and African Studies, University of London, London WC1H 0XG, UK; \\ alyaa_ebbiary@soas.ac.uk (A.E.); 655836@soas.ac.uk (H.P.); 657735@soas.ac.uk (J.S.) \\ 2 Shams Ad Duha Mohammad, Ebrahim Community College, London E1 1EJ, UK; \\ shamsadduha@gmail.com (S.A.D.M.); safiyyadhorat@gmail.com (S.D.); shahanaz_b@hotmail.com (S.B.) \\ * Correspondence: as150@soas.ac.uk
}

Received: 26 September 2019; Accepted: 3 December 2019; Published: 5 December 2019

\begin{abstract}
The Universities and Muslim Seminaries Project (UMSEP) addresses three key issues in the narrative of Muslim communal identity and religious leadership in Britain today: firstly, the need for the accreditation of Darul Ulooms (Muslim seminaries) and external validation of their programmes; secondly, understanding the career trajectories of Darul Uloom graduates, and exploring good practice; thirdly, understanding emerging leadership models in the British Muslim community. This project is a community-led, positive response to a large Arts and Humanities Research Council (AHRC)-funded research project (Re/presenting Islam on campus) conducted between 2015-2018, which identified discrimination against Muslim staff and students and the politicization of their identity due to counter terror securitisation measures. The community project summarized here in interim form proposes powerful and informed antidotes to discrimination: pathways to mutual recognition in higher education. We used interviews, workshops, and surveys and triangulated our findings to draw our draft conclusions. Firstly, we found enough interest in universities and Darul Ulooms to proceed with accreditation for an Islamic course with the same standing as a degree. Secondly, we identified barriers to career pathways for Muslims. Thirdly, we developed new models of Muslim community leadership, most notably Muslim chaplaincy with spiritual components: a career path with specific significance for Muslim women.
\end{abstract}

Keywords: Darul Uloom; seminary; chaplaincy; accreditation; servant leadership; paraguiding; the jurisprudence of reality

\section{Introducing Paraguiding and the Jurisprudence of Reality}

The Muslim seminary tradition is often viewed as a version of Islamic spirituality that offers exemplary Islamic scholarship unrecognized by mainstream education: in order to maximize its potential and relevance, this traditional approach requires contextualization so that it can be understood more widely, and its wisdoms applied to daily life. This is a form of the 'jurisprudence of reality' that transcends the divide between theory and practice in order to support all communities to communicate better and function co-operatively (Scott-Baumann 2007; Mukadam et al. 2010). The jurisprudence of reality is translated from the Arabic fiqh al-waqi, a concept used to apply and understand classical Islamic law through the prism of today's world.

Here, we set out for the first time a summary of the achievements of a new project, the Universities and Muslim Seminaries Project, which considers the three major issues outlined above. We draw 
on the work of Mahmood, Naguib, Bano, Scott-Baumann, Ebbiary (Ebbiary 2017), Vygotsky and others to demonstrate project innovation and to address chaplaincy and curriculum improvement. The Universities and Muslim Seminaries Project (UMSEP) project team, guided by Scott-Baumann, has developed documentation that will facilitate various aspects of accreditation. Furthermore, the UMSEP project, guided by the Muslim women scholars in the team, has developed a new form of leadership for women and men that involves working alongside those who wish to learn. We call this 'paraguiding', in the sense of 'para' meaning beside or next to and 'guiding' in the sense of facilitating supporting others by actively using one's own social agency as both teacher and learner. Both learner and teacher may go through a similar process of self-discovery and this is inspired partly by the servant-leader model and partly by Vygotsky's pedagogic zone of proximal development. Paraguiding contains elements of intellectual, spiritual and emotional striving which can be seen in each of the following approaches in different ways: the new Ebrahim College chaplaincy model, the academic improvement of the Darul Uloom female curriculum led by Begum, and analysis and distillation of contemporary women leaders' experiences by Ebbiary.

\subsection{The State of Darul Ulooms and Islamic Higher Education in the UK}

The training of British Muslim faith leaders has been an area of interest and concern for both Muslim communities and governments for decades. The earliest Islamic theological college in the UK was founded in 1975. Since then, such colleges, commonly known as Darul Ulooms, have proliferated across the UK, and the demand for the alimiyyah programmes which they provide has continued to grow. The alimiyyah, a course of approximately $4-6$ years duration, is a thorough training in the Islamic textual, legal and theological canon. More recently, with the founding of Ebrahim College (2003), the pedagogy and course structure through which the traditional alimiyyah programme is delivered has been reappraised. It is important to note here that the alimiyyah programme is degree-equivalent training offered in different parts of the Muslim world but, in the UK context, it is taught according to the Dars Nizami syllabus, which has its origins in the clerical training programmes of the Mughal Empire.

Despite the alimiyyah programme not being recognized by most universities, or by most employers, many graduates have progressed onto BA and MA programmes, and some are also PhD holders. Others have realised their potential and fulfilled their talent in other meaningful ways, such as teaching Islamic sciences, running institutes, and community work. Some have trained in professional fields unconnected to their prior education. However, others have found the lack of accreditation limiting. Whilst seminary graduates tend to have the commitment and initiative to find ways of earning, often their salaries are limited by the nature of the labour markets they can enter, and the theological training they have received may not be utilized well to the benefit of their communities and wider society.

\subsection{Definition of Darul Uloom}

The Universities and Muslim Seminaries Project (UMSEP) proposes the following working definition of an Islamic seminary:

'An Islamic seminary is an institution that teaches an alimiyyah or other scholarly training programme, that aligns with the religious authority and curriculum goals of a tradition of higher learning in the Islamic world. Such traditions of higher learning may include the Darse Nizami curriculum, which is popular in the Indian sub-continent, or any model established in other parts of the Muslim-majority world. As institutions of higher education, the training is usually offered to post- 16 students whom it trains for scholarship in the Islamic sciences and/or service of the community as faith leaders. These institutions may come under the names Darul Uloom, madrasa, Islamic college (Kulliyyah) or University (Jamia), or others.'

Although this definition falls into the category of Further and Higher Education in the UK context (FE and HE), this does not acknowledge the dozens of institutes across the country that 
offer the alimiyyah programme to students under 16 . For the purpose of this project, we will not be including them.

\subsection{Why Darul Ulooms, and Why Now?}

In the British government's 2018 Integrated Communities and Strategies Green Paper, the government committed to:

Conven[ing] a working group to identify the barriers to Darul Ulooms (Islamic theological institutes) and other religious seminaries achieving higher education accreditation of the qualifications they offer.

... This working group will identify the barriers to Darul Ulooms and other religious seminaries achieving accreditation for their courses from British universities, which government will then seek to act on. (p.61)

The Ministry of Housing, Communities and Local Government commissioned Scott-Baumann to lead this working group, which became the Universities and Muslim Seminaries Project (UMSEP). Objectives were proposed and agreed by the research team with the Ministry of Housing, Communities, and Local Government (MHCLG) to explore the barriers to accreditation and also to map Muslim seminary graduates' current career trajectories. A particular emphasis was placed on Muslim scholarship and leadership, and a sub-committee was formed in March 2019 to advance understanding and formulate specific proposals for them. This report is the result of a five-month investigation, and constitutes the first phase of what we expect will be a five-year project that will lead to a template and model through which the UK's traditional Muslim seminaries (over 40) will be able to work towards the accreditation of their courses and establish excellent working relationships with regional universities.

Whilst the accreditation of Darul Ulooms has been an area of speculative interest for decades, it would appear that it is now that the idea's time has come. Various factors have made this possible. Firstly, over a decade, Ebrahim College has restructured its alimiyyah programme and pedagogy to align with the National Qualifications Framework, thereby making the Islamic sciences taught in Darul Ulooms intelligible to the university sector, and possible to accredit. Secondly, interest in accreditation in the Darul Uloom sector is growing fast, and the will and energy is, for the first time, increasingly present. Most notable in this respect is the long-established and reputable Jamiatul Ilm Wal Huda (Blackburn), whose rector is very supportive. Furthermore, a Jamiatul Ilm Wal Huda graduate, Haroon Sidat, recently completed his $\mathrm{PhD}$ - an ethnographic study entitled Formation and Training of British Muslim Religious Leadership Muslim Scholars (Ulama): An Ethnography of a Dar al-Uloom in Britain (Sidat 2019). A third factor is that St Mary's University, a willing partner, was granted powers to award its own taught degrees in September 2006, and now has over a decade of experience in validating Catholic seminary courses. The aligning of other factors too makes this project well timed, and able to deliver long-term success. These factors include some concerns in some parts of government about the securitisation of public space in an attempt to reduce 'extremism'. Another element is the strength of a few respected and influential agents for change such as Tim Winter (Abdal Hakim Murad, Dean and Aziz Foundation Professor at Cambridge Muslim College) who urges renewal of Islamic higher education:

'The UK Darul Ulooms typically follow a curriculum which represents 19th and early 20th century reforms to a 17th century North Indian curriculum. It was the intention of the reforms to reduce the emphasis on logical, philosophical and jurisprudential topics in order to place more stress on Hadith and Sharia studies. In the UK context where critical intellectual skills are the basis of academic life this transformation has poorly equipped Darul Ulooms to enter the mainstream higher education sector.' (UMSEP archive 2019)

Accreditation has been achieved by Cambridge Muslim College and a few others and is a long term goal for some Darul Ulooms: of immediate use and impact is the toolkit developed as part of the project by Ad Duha Mohammad, Ebbiary, Begum and Dhorat in order to help universities and academics in 
the field of Islamic studies to understand Islamic seminaries, such as Darul Ulooms, and the nature of their curricula. Finally, in the broader context of the national discussion about Islam, we contextualised our work within the findings of the Arts and Humanities Research Council (AHRC)-funded project 2015-18 Representing Islam on Campus (Scott-Baumann et al. 2020). The AHRC project has, at the time of writing, the largest data sets yet collected (both quantitative and qualitative) about Islam on campus and two of the case study institutions are Muslim colleges: analysis shows clearly that the Muslim colleges have a great deal to offer mainstream universities in terms of a range of personal Islamic identities including articulation of citizenship, cultural as well as secular understanding and academic scholarship. These features are corroborated in our current project.

\section{UMSEP Objectives, Methodology and Findings}

Outlined below are the nine objectives that were agreed with the Ministry of Housing, Communities, and Local Government (MHCLG) for this five-month project-all were fulfilled, and often exceeded:

1. Select three universities and three Darul Ulooms: Collaborations and partnerships were established with Ebrahim College and St Mary's University in London, the University of Birmingham, Al-Mahdi Institute and As-Suffa Institute in Birmingham, and the University of Leeds and Jamiatul Ilm Wal Huda (Blackburn) in the North.

2. Provide a list of existing models in the university sector for Darul Uloom graduates.

3. Map Darul Uloom graduates' pathways into higher education.

4. Develop a universal Darul Uloom toolkit that align alimiyyah programmes with the National Qualifications Framework so they can be understood by university admissions officers.

5. Run three workshops with St Mary's University and Ebrahim College: Conducted on the campuses of both institutes, the workshops furthered the process that we expect will lead to Ebrahim College being the first UK Muslim seminary to gain university accreditation for its alimiyyah programme.

6. Run three workshops for Darul Uloom teachers: Participating teachers were introduced to the National Qualifications Framework by Dhorat and Begum and were guided through the process of recasting their Darul Uloom syllabus to align with the National Qualification Framework (NQF). This constitutes the first step of a wider programme of crystallizing learning objectives of each taught text, shifting from a book-based to a subject-based curriculum, and raising pedagogic standards with the eventual goal of achieving accreditation.

7. Work with a women's Darul Uloom to ensure equal access to university courses by mapping the curriculum onto the National Qualifications Framework so that it can be replicated in other women's Darul Ulooms.

8. Interview key women to develop a mentoring programme for women, that will increase their community influence

9. Partner Islamic Studies teachers in universities with Darul Ulooms: A wider goal that will serve Darul Ulooms is our work with St Mary's Catholic University, the University of Birmingham, the University of Leeds, School of Oriental and African Studies (SOAS), and the University of London to consolidate the Common Awards system by analogy with that set up at Durham University by the Church of England. The Common Awards system facilitates parity across religious training in the Church of England. It requires constant diligence to pre-empt universities falling back into older, more conservative habits that retreat from partnerships with Muslims, and to encourage more conservative Darul Ulooms to run such programmes.

\subsection{Accreditation: Ensuring a Contextualized University Curriculum}

The need for the modernization and accreditation of classical Islamic theology courses has been accepted for some time (Gilliat-Ray 2005; Geaves 2012; Geaves 2015; Mukadam et al. 2010). Accreditation is a practical process that will empower young adults from traditional Muslim seminaries 
to be officially rewarded for their expertise and to enhance their career possibilities. Coexistence in society is the focus:

'... analysis as a mode of conversation, rather than mastery, can yield a vision of coexistence that does not require making others' lifeworlds extinct or provisional'. (Mahmood 2005, p. 199)

The discourse of 'integration' in much of the British political and cultural sphere focuses upon the responsibility of minority actors to adapt and move toward the majority (Scott-Baumann 2018). As the quote from Mahmood suggests, there may be a loss in this movement, and, in the context of UK universities, there is potential for enrichment through a connection with Muslim seminaries. Young Muslim men and women will no doubt benefit from these developments in terms of academic success, career progression, salary enhancement and understanding of their own and other cultures. We hope to be able to report in a few years that an acceptance of modest Islamic virtues onto campuses may make it possible to offer alternatives to mainstream campus misogyny, related to campus contexts (offline and online) that can be affected by alcohol use and sexualisation of friendships (Phipps and Young 2012). The recent AHRC project confirms in fact that most university students welcome the presence of religion on campus as a benevolent influence (Scott-Baumann et al. 2020).

Indeed it is highly relevant for the elucidation of our current project to accept that cultural recognition of other belief systems is an important goal to strive for: we see this in our work with universities and Darul Ulooms, where it is also necessary to accept that there are significant institutional and cultural differences and that they must be acknowledged and discussed in order to develop clear working relationships (Scott-Baumann 2003, 2017; Cheruvallil-Contractor and Scott-Baumann 2015).

It is necessary that universities acknowledge religious understanding in order to work with people of faith, and it is also necessary that Darul Ulooms recognise secular understanding in order to work with universities. Amongst the approaches adopted by Muslims, some choose to exclude tradition in favour of secular critique, whilst others choose to uncritically accept traditional approaches in favour of pursuing pure lives. All parties will need to make adjustments, to build a society that is moral together, and we hope to facilitate this. We believe that such co-operative approaches will facilitate avoidance of the extreme poles of the debate. As a result, we also expect that in the future more women will be able to participate actively in legal reasoning, thereby bringing female perspectives to Islamic religious authority, and the interpretation (in the modern world) of theological and legal understandings (Naguib 2010). We will show here how this may become possible by changing certain structures to reflect the fact that women may have different views from men on certain topics.

\subsection{Bridging the Gap between Darul Ulooms and Universities: The Toolkit}

One of the key outputs of the project has been to produce a toolkit for universities and Islamic seminaries to understand each other. It was designed by UMSEP researchers with considerable experience in the workings of both Islamic seminaries and the UK's higher education system. The toolkit is a unique exercise in bridging the gap between different intellectual traditions and institutions. Apart from the details it outlines below, this clear exposition of what the seminary does and how it corresponds with university education also creates diverse opportunities for collaboration and partnerships with seminaries. These could aid seminaries develop their curricula to align better with further and higher education frameworks and explore validating partnerships. It can also serve as a reference point for employers to understand the academic background and skills of seminary graduates in the same way that QAA benchmarks and published university syllabi do.

The toolkit will help universities and other stakeholders in the following ways:

1. Understand the full breadth and depth of the seminary curriculum and where it corresponds with their own Islamic studies programmes. 
2. Serve as a reference point for universities' admissions departments by providing a full picture of the seminary graduate's academic history at level 3 (AS/A level) and levels 4, 5, and 6 (undergraduate level).

3. Create diverse opportunities for collaboration and partnership.

4. Facilitate seminaries and universities fully exploring the possibility of validating partnerships.

5. Serve as a reference point for employers to understand the academic background and skills of seminary graduates in the same way that QAA benchmarks and published university syllabi do.

6. Support seminaries in developing their own curricula within the context of British further and higher education frameworks.

\subsection{Helping Universities Understand Muslim Seminaries}

The toolkit also contains the following information about seminaries:

1. A definition of an Islamic seminary,

2. An overview of the key features of UK seminaries,

3. An overview of the seminary curriculum,

4. A detailed explanation of the Islamic sciences, and

5. A list of seminaries that are producing faith leaders and teaching at levels that overlap with higher education.

Another approach was through holding meetings and workshops with key personnel from As-Suffa Institute, Al-Mahdi Institute, a London Women's Darul Uloom ${ }^{1}$, St Mary's University, the University of Birmingham and the University of Leeds.

On each occasion, the activities brought together individuals who would not normally meet:

1. St Mary's (RC, Protestant and other) hosted a workshop with Ebrahim College staff and students (Muslim);

2. Al-Mahdi College (Shi-i Muslim) hosted a workshop with the University of Birmingham (secular), Ebrahim College (Sunni Muslim) and As-Suffa Institute (Sunni Muslim);

3. London Women's Darul Uloom and Ebrahim College hosted meetings and workshops with young Muslim women students who had not previously worked with co-ed or male Islamic seminaries.

In each case, significant barriers were removed. For example, the University of Birmingham and Al-Mahdi representatives were sceptical of Sunni Darul Ulooms academic levels prior to being introduced to Ad Duha Mohammad's sophisticated mapping exercise, and the detailed information of modules run at Ebrahim College.

\subsection{Understanding Career Trajectories of Darul Uloom Graduates}

Because their seminary studies are not recognized by the mainstream, rather than entering graduate-level employment or post-graduate education directly, British Muslim seminary graduates often need to study for undergraduate degrees all over again. With university fees being prohibitive and interest-bearing student loans religiously contentious, the problems extend beyond time and age. In particular, young female graduates may be reluctant to pursue university education, despite a keen desire to do so, due to being unfamiliar with the secular environment, or to respect family wishes. Thus, their educational and economic opportunities-for the duration they wish to engage in them-can be more limited and less rewarding than for their male counterparts (Cheruvallil-Contractor and Scott-Baumann 2015).

The UMSEP survey was collaboratively compiled by the UMSEP team using Google Forms. After piloting it with selected Darul Uloom graduates, it was revised and disseminated to graduates

1 The institutional participants wished to remain anonymous. 
of Sunni Darul Ulooms across the UK, of both Deobandi and Barelwi orientation. Primarily, graduate networks were tapped into via the social media platform, 'WhatsApp,' through personal acquaintances belonging to 'WhatsApp' alumni groups, who also shared the survey widely. The link for the survey was preceded by a message detailing its purpose. The survey questions were mostly open-ended, using short or long answer response fields. Whilst multiple-choice questions on gender and study mode were restricted, other multiple-choice questions, such as the type of activity pursued upon graduating had 'other' as an option, which also invited open-ended input.

To date, the survey has generated 221 responses countrywide, from alumni of male and female Islamic seminaries, who predominantly graduated between the ages of 16 to 25 -thirteen respondents were over 25, with the eldest being 53. The number of responses makes this the most extensive survey ever done in this field, and, uniquely, over $35 \%$ of the respondents (81) were graduates of female Darul Ulooms. Coding of the survey data has been done for the following questions: region of home town; which Darul Uloom the individual graduated from; the field and level of education pursued upon graduating; the route to admission to university; the ease of admission to university; the field of employment entered upon graduating from Darul Uloom/from university; subsequent fields of employment; current field of employment; the types of community service performed. Whilst some preliminary findings can be noted, a statistician is yet to conduct a thorough analysis.

The large majority of Muslim seminaries in the UK do not offer any externally validated qualification at the end of their programmes, thus placing graduates at a disadvantage when applying for university or employment (Gilliat-Ray 2005). The survey revealed that access to Higher Education courses, usually run at colleges, have offered a pathway for several graduates. Furthermore, progressing onto further and higher education was a popular route taken upon graduating from Darul Uloom, be it at a college or university, or an Islamic institute. Almost 35\% of respondents (77) graduated with a BA, and $18.5 \%$ with an MA/ PGCE (41). Of the MA/ PGCE holders, close to $8 \%$ (17) enrolled directly onto their programme without a BA, predominantly in the field of religion/ Islamic Studies (13). Some would combine their studies with a form of employment. Others would return to studying after other pursuits. The range of subjects studied at BA/BSc level (single honours or combined) included Audiology, Biomedical Science, Building Surveying, Business Management, Business Information Systems, Chemistry, Civil Engineering, Communication Media Studies, Criminology, Computer Science \& Internet Technology, Deaf Studies, English Language \& Linguistics, English Literature, Forensic Psychology, Interdisciplinary Human Studies, Journalism, Law, Optometry, Primary Teaching \& English with QTS, Public Health, Social Studies, Sociology, and TESOL. Subjects studied at MA/ MSc include Accounting, Building Surveying, Engineering, Journalism, Law, Social Care Policy, TESOL, Translation, Pharmacy, Philosophy, Psychology, and Special Educational Needs. From the 77 BA holders $78 \%$ (60) secured employment in professions that were not related specifically to religion (i.e. not religious teaching, chaplaincy, or imaamat). Looking at the $41 \mathrm{MA}$ holders, the percentage rises to $85 \%$ (35). Fields of employment included construction, health, IT, finance, law, management, media, retail and teaching.

Though the survey results seem promising in terms of the ambition and resourcefulness of seminary graduates in seeking out Higher Education and gainful employment, their path is often far from straightforward and may be difficult: for various reasons-including financial—some of those who would aspire to, do not make it onto university degree programmes. Perhaps even more problematic is the constraint on directly applying for grants and then later for graduate-level employment positions. Furthermore, Islamic seminary graduates tend to have instilled in them a sense of duty to serve community and society, and the survey has generated plentiful data on the various forms this takes. Detailed quantitative and qualitative analysis of all these areas is due to be undertaken in the next phase of the project. 


\subsection{Emerging Leadership Models}

As long as 15 years ago, Lewis (2006) reflected upon the new social roles emerging among the graduates of the Darul Ulooms. Many of these young graduates (in this case male) were forging paths into community service and leadership that their training did not equip them for, nor even intend. This is in large part because the Dars Nizami syllabus taught at British Darul Ulooms is descended from an Indian Muslim intellectual tradition that was geared to producing civil servants for the Mughal Empire, not necessarily youth workers and local mosque Imams in England. Some of the roles, such as interfaith facilitator, media spokesperson, speaker on the campus circuit, prison or hospital chaplain, and others, are quite alien to the bookish emphasis of many Islamic seminaries.

The third major theme of the UMSEP project is to identify and acknowledge some of the new leadership models that young Muslim seminary graduates are taking up and understand the pathways they are pioneering and laying out for future generations. This is particularly necessary for the increasing cohort of female Islamic scholars who are re-establishing traditional roles by entering the Muslim community.

Due to the various exploratory strands of this project, several methodological approaches were adopted. For the survey, we relied upon snowball sampling, which proved very effective considering the hard-to-reach demographic of Darul Uloom graduates. As mentioned earlier, the survey was devised collaboratively and tested before use, and the results will be statistically analysed.

Interviews were undertaken for the project strands related to women leaders and chaplains. In total, 13 interviews were conducted-seven with Muslim women leaders, and six with chaplains, both men and women. Interviews were approximately an hour in duration and questions focused upon the career trajectories of both groups. For the women leaders, questions centred on avenues and obstacles to religious authority in the community. For the chaplains, questions related to understanding the current terrain of chaplaincy work, and the potential for Muslim and female practitioners in that field. At time of writing, analysis of interviews was ongoing. All participants were guaranteed anonymity, confidentiality and right to withdraw at any time. All the interviews were recorded unless participants stipulated otherwise, in which case verbatim notes were taken. Most interview participants requested to be anonymised. Some, who are named here, gave permission for their names to be used. With regard to confidentiality, we made it clear that the taped transcripts would be shared with a transcriber from outside the project team and, as the project is government funded, there was a possibility that parts of the data would be seen by the funders. This required a process of detailed exposition of the research and dissemination process to the participants for the purpose of reassurance. This is understandable considering the difficult relationship between British Muslim communities and recent successive governments, as well as the feeling of scrutiny and surveillance experienced by British Muslims, be it from media or political power.

In other strands of the project, less conventional methods were utilised. One key strand was the curriculum mapping exercise with the women's seminary. This was a unique collaborative and reciprocal activity of direct benefit to participants and researchers. As many of the seminaries can be very private and insular, building trust and credibility was a major obstacle, but the results were fruitful. Finally, the workshops we organised, hosted by various seminaries and mainstream universities, were primarily aimed at the purpose of bringing together: (a) Darul Ulooms from different backgrounds to learn from each other, and (b) Darul Ulooms and universities to start a conversation about collaboration. We used a mapping exercise that involved three sequential steps: identifying key Islamic texts, then mapping them onto the university curriculum for religion and subsequently identifying and explaining the knowledge and skills required for non-experts. This model provided clarity in formulation of objectives, assessments and pedagogy and produced a template that can be used elsewhere. These workshops were highly successful in their primary purpose, and though data collection was not a primary intention of this strand, they did inform our research trajectory and help acquire future partners. 


\subsection{The 'Jurisprudence of Reality'}

In all intellectual traditions, be they religious or academic disciplines such as psychology, there is a gap between the theory and the practice. In Islamic discourse, the idea of a jurisprudence of reality, which is a translation of the Arabic fiqh al-waqi', seeks to address this gap and to understand better the ways in which legal rulings work out in Muslim society. The idea of fiqh al-waqi' (in those terms) has been used by a number of public Islamic Scholars such as Shaikh Yusuf al Qaradhawi (see Caeiro 2017). However, the idea has been debated and expressed in other ways among Islamic scholars the world over. Though many in the South Asian influenced Darul Uloom world would assert that the fatwa tradition (fatwa is the act of creating new legal opinions) is robust and adequate enough to deal with the ever changing modern world, there are a number of scholars from the tradition who have upheld a more context-led reappraisal ${ }^{2}$. Apart from the Islamic legal approach to applying fiqh (Islamic jurisprudence) to 'facts on the ground', there have been a number of anthropological analyses of this bridging activity: most relevant for this context is the work of Bowen (2016) who studied Sharia courts in Britain.

Resonating with the jurisprudence of reality, one of the key emerging leadership roles for Islamic religious professionals in the modern UK context is that of chaplaincy. How can we create accessible spirituality that facilitates humane conversations and mutual recognition, even if not mutual understanding? Whilst Islamic jurisprudence has developed extensively over the centuries, the idea of an Islamic pastoral theology has not. Yet, more recent institutes, such as Cambridge Muslim College, White Thread Institute and Ebrahim Community College are rebalancing the debate. Indeed, as noted by Ali and Gilliat-Ray (2012), Darul Uloom graduates working in chaplaincy are engaging in legal reasoning-regarding what is haram and halal in the context of British public institutions, as well as inspiring an emerging 'theology of pluralism' and 'theology of pastoral care'.

By analogy, the idea of the jurisprudence of reality can be adopted by those who wish to enhance the capacity of Muslims to find a space in which they can explore alternative views to the formulaic ones, and to facilitate the personal futures that may need to be mapped out for an individual with a question, a dilemma or a problem. This need is identified by women interviewees in our project, who state that there is a need for chaplains to master:

'practical theology to complement their theoretical studies ... and what is needed in chaplaincy is the ability to contextualise theology and adapt to this [workplace] context-Darul Uloom graduates have not been taught to contextualise in this way.'

(UMSEP archive 24 June 2019)

\section{7. "Paraguiding" and Chaplaincy}

Our 2019 findings demonstrate a powerful evolution in the perception of chaplaincy which, in the 1980s was often still viewed as a Christian device. This justifies our emphasis in this paper upon chaplaincy as a dominant aspect of the creation of new career pathways for Darul Uloom graduates.

The religious diversity of Britain should surely suggest the need for proper national chaplaincy provision in places of public service and public education. As Aune, Guest and Law show in their 2019 report, there have been developments and we see this evolving in earlier reports (Aune et al. 2019). Gilliat-Ray's Religion in Higher Education: The Politics of the Multi-faith Campus (2000) and Ataullah

2 These include luminaries such as Mufti Taqi Usmani and Mufti Khalid Sayfullah Rahmani. The latter has a famous book called (Jadid Fiqhi Masail, i.e., 'new jurisprudential issues') and is also the general secretary of the Indian Fiqh Academy. The first two objectives in the English brochure of the IFA reads as follows: '1. To find solutions for the contemporary problems brought up by the developments and changes in social, political, economic, industrial and technological spheres of life, in the light of the guidelines provided by the Quran and Sunnah and deliberations and interpretations of the companions of the Prophet and other pious classical jurists and scholars. 2. To make collective efforts to find out solutions to the contemporary problems or those problems of past which demand rethinking and research in the changing circumstances in line with the principles and methodology of Fiqh.' 
Siddiqui's valuable report on Islam at Universities in England (2007) both contain helpful chapters on the developing character of chaplaincy among Muslim students. Between 2008 and 2012 Professor Sophie Gilliat-Ray, Mansur Ali and Stephen Pattison conducted the first systematic study of Muslim chaplaincy in the UK (2008-2012, funded by Religion and Society). They found that the appointment of Muslim chaplains in prisons and hospitals since the 1990s has positively influenced chaplaincy and Islam in Britain. Their research, culminating in the book Understanding Muslim Chaplaincy, identified how much excellent chaplaincy support goes unnoticed and argued for better funding, understanding and appreciation. They also discuss Dr. Ataullah Siddiqui's unique Markfield Institute of Higher Education (MIHE) Certificate in Muslim Chaplaincy (2013, pp. 5-11) and show how the terms 'chaplaincy' and 'pastoral' have been adopted and adapted by Muslim practice. Chaplaincy gives new opportunities to Muslim men, and especially Muslim women, to function in the secular public space as agents of religious caring (Gilliat-Ray et al. 2013, p. 165).

We wish to draw attention to the evolution of this model, related partly to the involvement of Ebrahim College (Ad Duha Mohammad) and Markfield Institute of Higher Education (Ataullah Siddiqui) in developing new and Islamic approaches to chaplaincy. In 2008-2012, Gilliat-Ray's research with Muslim chaplaincy identified that Muslim chaplains often pay close attention to legal rulings of Islam, i.e., practical/correct behaviour, whereas for Christian chaplains, 'correct' practice was not that important (p. 169). In the intervening years, this difference has altered, as argued by Rajput (2015). Yet our work develops a new approach that leads to new practices, neither focusing more upon humanitarian care (Rajput), nor upon theological accuracy (traditional seminary): we show how Muslim chaplaincy can develop a coherent combination of counselling/social work/pastoral support with theological application of key moral tenets.

Our research shows that Muslim chaplaincy is now evolving and is valued by Darul Uloom graduates, especially women, who understand the potential of their faith and their soft skills in this context. Most of the Darul Uloom graduates who were interviewed now see chaplaincy as a logical career progression: they describe Darul Uloom training as really important-without this Muslim chaplains would not have theological resources to turn to as they need to have a good grasp of Qur'an and Hadith. Most importantly, in our view, several also saw a reciprocal relationship between their textual and legal understandings and their work as chaplains: they described chaplaincy as a necessary contextualisation of their Darul Uloom studies: their descriptions evoke fiqh al waqi', the jurisprudence of reality. Some voices are critical. Tim Winter gave us his views on Darul Uloom education in his interview:

‘Darul Uloom students usually lack critical skills, comparative approaches, a historical sense of the emergence of Islamic doctrines and laws, and an awareness of wider global and Islamic trends. They are also not trained in essay-writing or the construction of arguments'. (UMSEP archive 2019)

Earlier we mentioned soft skills: by soft skills the chaplains we interviewed understand interpersonal aspects of relationships such as active listening, being non-judgmental yet always moral and having a religious opinion to offer in real situations: they see chaplaincy as both complementary to theology and also going beyond it. This 'going beyond' involves several features that emerged as a theme in interviews and shows understanding of a varied, complementary set of skills that are often reciprocal: in order to give help the one whose help is sought has to learn about the one who seeks help. We present them here (in no hierarchical order because they were intertwined during discussion and show the jurisprudence of reality). First, for a novice chaplain it's necessary to learn the skill of functioning like a counsellor by gaining experience through volunteering - it's wise to give this time and attend training courses in order to understand the context of chaplaincy: this includes the importance of presenting oneself as a professional and also as a moral and spiritual guide. We also have evidence of this perceived need for soft skills from within the Darul Ulooms and unrelated to chaplaincy, as evidenced by a senior woman teacher and Darul Uloom graduate: 
'We need counselling as we are expected to be a counsellor too. Not only should we be able to deal with fiqh questions, but we need to help people through emotional times'. (UMSEP archive 2019)

Secondly, it's necessary to come as a 'learner' to this work, to deal with the secular world and not come with a sense of entitlement gained from specialist theological knowledge. In his interview Tim Winter explained how the success of the Cambridge Muslim College Diploma in Contextual Islamic Studies and Leadership shows:

'the willingness of Darul Uloom graduates to gain non-traditional skills which will render them more relevant and employable in the UK'. (UMSEP archive 2019)

Thirdly, women have particular strengths in soft skills as we see in the Ebrahim College work and that of Cambridge Muslim College, which the senior Darul Uloom woman teacher also emphasised:

'Leadership skills are vital and how to deal with people of different ages. CEO type training is not useful. Rather it has to be grass roots focused and based on khidma (service).

Such qualifications would help us feel more confident.' (UMSEP archive 2019)

Here, we propose a new model of leadership, paraguiding, to create possibilities for contextualization, for practical wisdom and for challenging secular norms, inspired by the jurisprudence of reality, fiqh al waqi'. Paraguiding includes the skills clearly discernible in chaplaincy, and also encompasses good practice seen in Darul Ulooms. Paraguiding puts the emphasis upon reciprocity, being beside each other and even learning from each other, and we see this in the ethos and approach of Ebrahim College's new chaplaincy model. When interviewed for the UMSEP project, Dhorat described the process of training for chaplaincy at EC to be "Learning to sit with a problem, not just in a text-based way", which she believes is part of a guided process of "finding yourself". This guided process, when facilitated by 'open ended reflections and exploration of students' experiences, has been particularly useful in developing these skills and helping them to understand the work of being a chaplain' (UMSEP archive 24 June 2019).

There is clear understanding in the Muslim chaplaincy sector of the combination of skills and character traits necessary for this type of work. When asked what qualities, skills and qualifications graduates should have when looking into chaplaincy, a workplace chaplain described the exact combination that we envisage for the jurisprudence of reality:

- Academic background-sound knowledge of Islam, confident in interpretation, qualified theologian, good grasp of jurisprudence;

- Ability to contextualise and apply teaching appropriately e.g., what applies in local communities as an imam may not work as a chaplain;

- Ability to tailor guidance to individuals;

- Basic training in chaplaincy e.g., confidentiality, non-judgmental approach;

- Interfaith experience and background as chaplaincy teams tend to be multifaith;

- (UMSEP archive 17.06.19).

We propose that this set of skills requires three crucial moral zones: traditional theology, moral authority and reasonable pluralism. These moral zones reflect the three sides of modern Islamic authority that Masooda Bano captured in her recent project (Munnik 2019). As well as working with traditional institutions that train ulama such as Cairo's al-Azhar and the Darul Uloom in Deoband (Bano 2018a), Bano has also worked with newer institutions and scholars in Muslim-minority countries such as Zaytuna College (USA) and Ebrahim College (England) (Bano 2018b). She avers that authority in Islam comes from three sources: knowledge of Qur'an and Sunna (ilm); the moral authority of the scholar; and the scholar's ability to relate to the realities of the living context (Bano 2018a, pp. 30-31). Specific to the third aspect, she notes how Muslim intellectuals educated in the West are notable for 
having sought and received education that helps them to recognise arguments that are both spiritually strong and realistically reflective of a specific situation (Bano 2018b, p. 25). For example, in chapter 6 of her book, Bano describes how Ad Duha Mohammad, co-founder of Ebrahim College in East London and lead member of the UMSEP team, uses the juridical history of the term ikhtilāf (disagreement) to propose that reasonable pluralism is a wise approach. In this way, he is thereby precluding relativism, and proposing that it is not possible to legislate so that everyone squares their conscience with their social responsibility in exactly the same way. Bano presents Ad Duha Mohammad as an example of a Western-educated Muslim faith leader, brokering reasonable pluralism and this provided inspiration for our project.

\subsection{Paraguiding and Female Leaders}

Historically the narrative of religious authority in Islam has not been a male-only endeavour. Although the primary Prophetic figurehead is male, the official systems of religious knowledge-making and official roles of religious leadership have not unanimously excluded women. Women have been able to access higher religious education (but arguably not equally) and have been able to teach and preach as legal and textual scholars. However, the role of Imam or leader of congregational prayers has been invariably male (Bano and Kalmbach 2012; Hammer and Spielhaus 2013).

There are a number of women-only Muslim seminaries in the UK, which produce alimas (female Islamic scholars). These women are trained in the traditional Islamic textual and legal canon and can also have a stake in religious authority. Most of the women's Darul Ulooms in the UK, however, do not offer a curriculum as advanced as the male seminaries. This is partly due to a perception that female graduates will not choose to take up public leadership roles, or perhaps they are not encouraged to. However, those who do go on to serve in the community often become religious teachers in mosques and supplementary schools. Other emerging pathways for these women include chaplaincy, legal work, mediation, counselling and other forms of religious and community leadership.

However, many female seminary graduates do not pursue a vocation based upon their learning. This may partly be due to structural issues in the Muslim community, which, despite the Islamic tradition being historically open to women pursuing religious qualifications, has not yet sufficiently adapted to cater for the growing number of credible female religious practitioners: as such, opportunities for women to exercise their religious learning and authority tend to have been limited. Furthermore, because female-only seminaries typically, it seems, have opted not to formally emphasize post-seminary education and employment, leadership positions in the British Muslim community taken by women have tended to be by those that are not seminary trained; this may have had a role in undermining the religious credibility of female scholars. Giulia Liberatore's paper in this special issue addresses these aspects of leadership for women (Religions 2019, 10(11), 601; https://doi.org/10.3390/rel10110601). Liberatore placed the issues facing women into a wider societal context, when we interviewed her for this project:

'It's really hard to build a community and to support the women, and that's a really big problem because that's why women might start something but not necessarily continue with it. It's a problem for women in general, there are fewer women in high-end jobs. It's a fundamental structural, societal problem.' (UMSEP archive 2019)

Nevertheless, due to numerous factors including generational changes and the increasingly challenging context of British society and the economy, learned and ambitious Muslim women are beginning to make an increasing impact on their communities and wider society.

How should we articulate the spiritual and the interpersonal components of female leadership that our interviewees identify? To approach this, we draw on the extensive literature dealing with the servant-leader model, which is appropriate since the two concepts of spiritual leadership and servant-leadership are close, and both resonate with paraguiding. However, scholars have noted that the literature has little to say about the motives, values, and conditions that cause one to become a 
servant-leader (Yukl 2010; Freeman 2011). It has been suggested that spiritual individuals are much more likely to become servant-leaders than those who are not (Freeman 2011). This theory is quite plausible given that possessing spiritual values such as humility, integrity, and empathy/compassion are thought to facilitate servant-leadership (Freeman 2011).

Reciprocity is the key characteristic that connects these different approaches to human communication and understanding. We use the educational model of the zone of proximal development (ZPD) and the servant-leader model to inform our working practices in this project, and introduce the concept of paraguiding. This approach has allowed us to clarify the ways in which the paraguiding chaplaincy model is unique and based upon a model of reciprocity that makes explicit a dimension to spiritual leadership that is often latent or even absent.

Lev Vygotsky, the renowned Russian psychologist (1896-1934), partially developed a model known as the zone of proximal development, unfinished at his early death (Yasnitsky 2018). It seems that if he had developed it further, he would have elaborated the emotional, cognitive and spiritual aspects of the learner's personality, but it is generally used as a pedagogic instrument: the basic premise is that the teacher must know the level of understanding and competence of the learner in order to teach well. If we take this beyond mere functionality to a richer level of human interaction, it is clearly necessary for teacher and learner to communicate well with each other.

The servant-leader model presented by Greenleaf in 1978 also requires reciprocity in the acceptance by both parties, leader and follower, of the possibility of role reversal, humility and learning from each other, in a deliberate and sometimes risky rejection of traditional hierarchal models of leadership (Greenleaf 1978).

Both these approaches are integrated into the chaplaincy model developed here, because this model involves acceptance of reciprocal learning, and generates the possibility for the spiritual leader to also learn, as well as serving the person who requests their guidance.

Most interestingly, Sendjaya (2007) has even developed and validated a scale for measuring spiritual leadership. Pertinently, interview questions used in the development of the scale included: "Does the term 'spiritual leadership' or 'servant leadership' mean anything to you?"; "How would spiritual/servant leadership be different from other leadership approaches or styles?"; and "Do you think the concept and practice of spiritual/servant leadership in organizations can contribute to better organizational performance? How?" Sendjaya appears to combine the two concepts of spiritual and servant-leadership, but what is missing is the possibility of creating a safe space in the secular world for the religious and also for acknowledging the ethical and societal benefits for women in this career path. In our section on Muslim chaplaincy, we demonstrate the value and efficacy of paraguiding as a way of beginning to understand what it is that women bring to leadership.

As well as ethical, organizational, spiritual and societal reasons for adopting a new model of Muslim leadership as exemplified in chaplaincy, there are pedagogic reasons for advocating paraguiding. This builds on the model of teaching and learning developed by Vygotsky. Underpinning Vygotsky's model is the simple and powerful belief that in order to teach someone something new, it is necessary to first establish what that person knows. This is achieved by drawing attention to a notional 'zone' that exists between what I know and what I do not know, which Vygotsky labelled the 'zone of proximal development' (ZPD). Paraguiding proposes that women in particular, for complex cultural reasons, are often particularly suited to inhabiting a 'zone' with a learner to establish the learner's current expertise, and then propose, negotiate and construct next steps.

We also propose that paraguiding can facilitate the new and growing desire to combine theological wisdom with real-world engagement because of the special combination made possible by introducing chaplaincy skills into a situation hitherto dominated by textual and linguistic analysis and devotional quietude. Chaplaincy training creates the 'zone of proximal development' (ZPD): the 'zone' is the cognitive, emotional and spiritual area where the learner has not previously engaged with secular workplaces and is being guided by a person who, through their chaplaincy experience, has adapted to secular settings and can mediate between pure theological learning and its real world application. 
Once learnt through training, the Muslim chaplain can take the zoning technique and apply it when attempting to help others who come to seek their guidance, whether Muslim or not. Thus there is in this model a built-in sense of learning in order to teach: the trained chaplain works alongside the trainee chaplain and teaches the trainee skills that achieve two functions: the trainee changes her own approach and then also, once she has become a chaplain, uses that new insight of teacher as well as the techniques she has learnt, to support those who seek guidance. We describe this process initially here in transactional terms and, in the context of Muslim leadership, it should also be understood in spiritual terms, because the motivating impulse for the female Muslim chaplain is the wish to animate her faith in order that its energy and goodness can be made accessible to others, even if they are of a different faith or no faith. It is understood both religiously and in terms of counselling traditions that personal agency is crucial. For a person of faith, religious knowledge production is at the core of this process, embodied in expressions of sympathy and solidarity as well as in moral precepts drawn from the prophetic Islamic traditions.

Finally, it is not accidental that the term paraguiding sounds like paragliding, a sport not for the fainthearted that takes the human mind and body out of the comfort zone of both feet planted firmly on the earth. Learning anything new provides a challenge at some level to one's sense of self, and this is especially so for chaplaincy, which constitutes a space for spirituality in a secular system. As a Muslim healthcare chaplain said when interviewed, the key to becoming a good chaplain is to 'Get out of your comfort zone'. However, becoming a chaplain means that Muslim seminary graduates' feet are already on unfamiliar terrain in a professional setting which challenges 'theological understandings around multifaith environments, mixed gender environments (UMSEP archive 20 June 2019). Other challenges commented on by interviewees include the reality that Imams and pastoral officers have 'very different roles, and different qualification sets-the theology qualification equips you for advisory role, not necessarily mental health and wellbeing' and that there needs to be a bridge between theology and mental health wellbeing (UMSEP archive 24 June 2019).

The key is for seminary graduates to be paraguided safely through the experience. And prior to that, for the theological education offered to them to be contextualized through a jurisprudence of reality, combining rulings with reality.

\section{Conclusions}

Through UMSEP, we now have partners in seminaries and universities to enable regional partnerships and share best practice and expertise. As mentioned, we are also working to extend the Common Awards system. We hope that our new partners in seminaries and universities will enhance mutual recognition and understanding within society.

Islamic seminaries and university Islamic Studies departments, or universities teaching Arabic as a language, exist in the same societal space but often do not know enough about one another to work co-operatively. As such, the toolkit has some general information about Islamic seminaries, their purpose and their history. Of greater practical import is the curriculum map that details every subject taught at Islamic seminaries and how each level of teaching approximates to the national qualifications framework. Such practical measures will facilitate mutual understanding of spiritual and educational needs.

The three main themes of the project have already begun to bear fruit; firstly, facilitating accreditation through workshops, curriculum mapping, and the toolkit; secondly, understanding the career pathways of seminary graduates; thirdly, analysing emerging leadership models, with special attention to chaplaincy and female leadership. We have analysed these emerging leadership models through the concepts of jurisprudence of reality, the servant-leader model and Vygotsky's teacher/learner approach. In this conflicted modern world, we share, our project provides powerful evidence of generous reciprocity emerging between mainstream universities, Darul Ulooms and Muslim College higher education models. These models can be expressed by using the neologism of paraguiding which shows the potential combination of the theological understanding of Islam, 
the servant leader model of leadership and Vygotsky's zone of proximal development. This model includes but is not restricted to new chaplaincy models, which create the ability to interweave three crucial moral zones: traditional theology, moral authority through humility and reasonable pluralism as understood when secularism and religiosity communicate effectively through sitting together to learn from each other.

Author Contributions: Conceptualization, A.S.-B., A.E., S.A.D.M., S.B., H.P. and J.S.; Data curation, A.E., S.D., S.B., H.P. and J.S.; Formal analysis, A.S.-B., A.E., S.A.D.M., S.D. and H.P.; Funding acquisition, A.S.-B.; Investigation, A.S.-B., A.E., S.D., S.B. and H.P.; Methodology, A.S.-B., A.E., S.A.D.M., S.D., S.B. and H.P.; Project administration, A.S.-B., H.P. and J.S.; Resources, J.S.; Supervision, A.S.-B. and S.A.D.M.

Funding: Ministry for Housing, Communities and Local Government (MHCLG).

Conflicts of Interest: The authors declare no conflict of interest.

\section{References}

Ali, Mansur, and Sophie Gilliat-Ray. 2012. Muslim Chaplains: Working at the Interface of 'Public' and 'Private'. In Muslims in Britain: Making Social and Political Space, 1st ed. Edited by Waqar Ahmad and Ziauddin Sardar. London: Routledge, pp. 84-100.

Aune, Kristin, Matthew Guest, and Jeremy Law. 2019. Chaplains on campus Understanding Chaplaincy in UK Universities. Coventry: Coventry University, Durham: Durham University, Canterbury: Canterbury Christ Church University.

Bano, Masooda, and Hilary Kalmbach. 2012. Women, Leadership and Mosques: Changes in Contemporary Islamic Authority. Leiden: Brill.

Bano, Masooda. 2018a. Modern Islamic Authority and Social Change Volume 1: Evolving Debates in Muslim Majority Countries. Edinburgh: Edinburgh University Press.

Bano, Masooda. 2018b. Modern Islamic Authority and Social Change Volume 2: Evolving Debates in the West. Edinburgh: Edinburgh University Press.

Bowen, John R. 2016. On British Islam: Religion, Law, and Everyday Practice in Shari'a Councils. Princeton: Princeton University Press.

Caeiro, Alexandre. 2017. Facts, Values, and Institutions: Notes on Contemporary Islamic Legal Debate. American Journal of Islamic Social Sciences 34: 42.

Cheruvallil-Contractor, Sariya, and Alison Scott-Baumann. 2015. Islamic Education in Britain: New Pluralist Paradigms. London: Bloomsbury Academic.

Ebbiary, Alyaa. 2017. Re-examining the Decline Narrative: Cambridge Muslim College and the changing face of Imam training in Britain. In Imams in Western Europe: Developments, Transformations, and Institutional Challenges. Edited by Mohammed Hashas, Jan Jaap de Ruiter, Niels Valdemar Vinding and Khalid Hajji. Amsterdam: Amsterdam University Press.

Freeman, G. Thomas. 2011. Spirituality and servant leadership: A conceptual model and research proposal. Emerging Leadership Journeys 4: 120-40.

Geaves, Ron. 2012. The Symbolic Construction of the Walls of Deoband. Islam and Christian-Muslim Relations 23: 315-28. [CrossRef]

Geaves, Ron. 2015. An exploration of the viability of partnership between dar al-ulum and higher education institutions in North West England focusing upon pedagogy and relevance. British Journal of Religious Education 37: 64-82. [CrossRef]

Gilliat-Ray, Sophie. 2005. Closed Worlds: (Not) Accessing Deobandi dar al-uloom in Britain. Fieldwork in Religion 1: 7-33.

Gilliat-Ray, Sophie, Mansur Ali, and Stephen Pattison. 2013. Understanding Muslim Chaplaincy. Burlington: Ashgate Publishing Co.

Greenleaf, Robert K. 1978. Servant Leader and Follower. New York: Paulist Press.

Hammer, Juliane, and Riem Spielhaus. 2013. Muslim Women and the Challenge of Authority: An Introduction. The Muslim World 103: 287-94. [CrossRef]

Lewis, Philip. 2004. New Social Roles and Changing Patterns of Authority Amongst British 'Ulamâ. Archives de Sciences Sociales des Religions 49: 169-87. 
Lewis, Philip. 2006. Only Connect: Can the Ulema Address the Crisis in the Transmission of Islam to a New Generation of South Asians in Britain? Contemporary South Asia 15: 165-80. [CrossRef]

Mahmood, Saba. 2005. Politics of Piety: The Islamic Revival and the Feminist Subject. Princeton and Oxford: Princeton University Press.

Mukadam, Mohamed, Alison Scott-Baumann, Ashfaque Choudhury, and Sariya Contractor. 2010. The Training and Development of Muslim Faith Leaders: Current Practice and Future Possibilities; London: Communities and Local Government. Available online: https://assets.publishing.service.gov.uk/government/uploads/system/ uploads/attachment_data/file/6155/1734121.pdf (accessed on 19 November 2019).

Munnik, Michael B. 2019. Answering for Islam: Journalistic and Islamic Conceptions of Authority. Religions 10: 435.

Naguib, Shuruq. 2010. Horizons and limitations of feminist Muslim hermeneutics: reflections on the menstruation verse. In New Topics in Feminist Philosophy of Religion: Contestations and Transcendence Incarnate. Edited by Pamela Sue Anderson. Dordrecht: Springer Press, pp. 33-49.

Phipps, Alison, and Isabel Young. 2012. That's What She Said: Women Students' Experiences of 'Lad Culture' on HE Campuses. Sussex: University of Sussex.

Rajput, Asgar H. 2015. The Role of Muslim Chaplains in Higher Education: Should They Be Doing What They Are Doing? Practical Theology 8: 227-44. [CrossRef]

Scott-Baumann, Alison. 2003. Teacher education for Muslim Women: Intercultural Relationships, Method and Philosophy. Ethnicities 3: 243-61. [CrossRef]

Scott-Baumann, Alison. 2007. Collaborative Partnerships as Sustainable Pedagogy: Working with British Muslims. In Greener by Degrees: Exploring Sustainability in HE Curricula. Edited by Carolyn Roberts and Jane Roberts. Cheltenham: University of Gloucestershire: Centre for Active Learning, Section C4.

Scott-Baumann, Alison. 2017. Trust within reason: how to trump the hermeneutics of suspicion on campus. In Muslims, Multiculturalism and Trust, 1st ed. Edited by Amina Yaqin, Peter Morey and Asmaa Soliman. New York: Palgrave Macmillan.

Scott-Baumann, Alison. 2018. United Kingdom. In Yearbook of Muslims in Europe. Edited by Oliver Scharbrodt, Samim Akgönül, Ahmet Alibašić, Jørgen S Nielsen and Egdūnas Račius. Leiden, Boston: Brill, vol. 9, pp. 711-30.

Scott-Baumann, Alison, Matthew Guest, Shuruq Naguib, Sariya Cheruvallil-Contractor, and Aisha Phoenix. 2020. Islam on Campus: Contested Identities and the Cultures of Higher Education in Britain. Oxford: Oxford University Press.

Sendjaya, S. 2007. Conceptualizing and measuring spiritual leadership in organizations. International Journal of Business and Information 2: 104-26.

Sidat, Haroon. 2019. Formation and Training of British Muslim Religious Leadership Muslim Scholars (Ulama): An Ethnography of a Dar al-Uloom in Britain. Ph.D. dissertation, Cardiff University, Cardiff, UK.

Yasnitsky, A. 2018. Vygotsky. An Intellectual Biography. London: Routledge.

Yukl, Gary. 2010. Leadership in Organizations, 7th ed. Upper Saddle River: Prentice Hall.

(C) 2019 by the authors. Licensee MDPI, Basel, Switzerland. This article is an open access article distributed under the terms and conditions of the Creative Commons Attribution (CC BY) license (http://creativecommons.org/licenses/by/4.0/). 